\title{
Judicial System in the Criminal Proceedings in Some CIS Countries
}

\author{
Umida Tukhtasheva
}

\begin{abstract}
This article examines the system of review of court decisions in criminal proceedings in some CIS (Commonwealth of Independent States) countries. The peculiarities of the verification of legality, validity and fairness of court decisions and the procedure for organizing the activities of higher courts are analyzed. The author also draws attention to recent changes in the criminal procedure legislation of such countries as Ukraine, Kazakhstan and Kyrgyzstan. Based on the results of the analysis of the system of methods of revision of court decisions functioning in foreign countries, the author makes conclusions about the similarities and distinctive features of the institute of revision of court decisions and puts forward proposals to improve the system.
\end{abstract}

Keywords: criminal proceedings, review of court decisions, cassation proceedings, appeal proceedings, supervisory proceedings, resumption of criminal proceedings in view of new or newly discovered circumstances, courts of higher instances, appeal of decisions, miscarriage of justice.

\section{INTRODUCTION}

The study of the system of judicial review in criminal proceedings in the CIS countries is of particular interest, as these countries share a common legal legacy. Since independence, the Model Code of Criminal Procedure, adopted on 17 February 1996, has laid down the main provisions of criminal procedure for CIS member States.

When developing the new CPC of the CIS countries, as noted by some processors, their developers and legislators tried to take as a basis the best international legal acts and traditions, which, from their point of view, could contribute to improving the efficiency of criminal proceedings $\mathrm{s}^{\mathrm{i}}$. An attempt has been made to maximize the applicability of international human rights instruments ${ }^{\text {ii }}$. Meanwhile, the analysis of the legislation of some CIS countries of that time shows that the issues of regulation of judicial review were not radically modernized and did not fully comply with some principles: for example, the principle of legal certainty, finality of court decisions. The majority of countries retained such proceedings as cassation, supervisory and reopening proceedings for newly discovered circumstances, which clearly demonstrates the existence of a number of verification instances rather than one, as well as the gap in the time of sentencing of the court of first instance with the time of possible revision of court decisions in subsequent instances of a higher court, which also undoubtedly affected the quality of review. Study of the results of a number of studies ${ }^{\mathrm{iii}}$ This issue allows us to conclude that the existence of a multitude of verification bodies alone cannot ensure the effectiveness of the review of court decisions and affect the quality of the examination of the case in previous instances. Moreover, the participants in the process do not allow themselves to fully develop all the versions and possibilities of both the prosecution and the defence, believing that there are still opportunities to turn to the institutions of judicial review ${ }^{\text {iv }}$.

Without stopping at the genesis of these institutions in the criminal process of some CIS countries, we decided to give an overview of the regulation of these institutions in countries such as the Russian Federation, the Republic of Kazakhstan, the Kyrgyz Republic and Ukraine, as countries whose legal framework is close to us and with whom we have established cooperation to a greater extent. The choice is also due to the fact that the latter countries have recently adopted and implemented new Criminal Procedure Codes.

The Code of Criminal Procedure of the Russian Federation establishes the following institutions whose activities are aimed at correcting judicial errors:

1) proceedings in the court of appeal - on the basis of court decisions that have not come into force;

2) proceedings in the court of cassation - on the basis of court decisions which have entered into legal force;

3 ) proceedings in the supervisory-instance court;

4) resumption of criminal proceedings due to new or newly discovered circumstances.

As noted above, a more updated system of review of court decisions is presented in the criminal procedure legislation of such CIS countries as the Republic of Kazakhstan, the Kyrgyz Republic and Ukraine. To date, the following ways of correcting judicial errors by higher courts have been established in these countries with little difference in name:

1) review of court decisions that have not come into force on appeal;

2) review of court decisions which have come into force in the cassation procedure;

3) resumption of criminal proceedings on newly discovered circumstances.

If we analyze the Russian system of review of court decisions, first of all, it should be noted that the appeal proceedings appeared in the CPC of the Russian Federation after the expertise of the Council of Europe of the draft CPC of the Russian Federation, where the Russian legislator was 
strongly recommended to provide for the possibility of appeal review of invalid court decisions ${ }^{\mathrm{v}}$. And as a result, a modern institute of appeal has been introduced in the Russian criminal procedure legislation. As noted by S.V.Zuev, K.I.Sutyagin, "Appeal proceedings are a stage of the criminal process, in which after appealing a sentence or other final court decision, which has not come into force, the criminal case is considered on the merits by a higher court within the framework of the submitted complaints and submissions. According to item 2 of item 5 of the Code of Criminal Procedure of the Russian Federation "the appeal instance is the court considering in an appeal order criminal cases under complaints and representations on the sentences, definitions and court decisions which have not come into force. The time limit for appealing such decisions is 10 days" $"$.

The subject matter of the appeal hearing shall be the decisions of justices of the peace and courts of first instance that have not entered into force. It is typical for appeal proceedings that the subject of appeal may be final (resolving the case on the merits) and interim (all the rest, such as definitions and decisions on the order of examination of evidence, rejection of petitions, etc.) court decisions.

Tasks of appeal proceedings are determined by the performance of control functions to verify the legality, validity, motivation and fairness of judicial decisions, which are: 1) Detection of factual and legal errors committed by justices of the peace and the court of first instance in the examination and resolution of criminal cases; 2) adoption by the court of appeal within its competence of decisions to eliminate the identified errors by reversal or amendment of decisions of the justices of the peace or the court of first instance $^{\text {vii. }}$.

In turn, the criminal procedure legislation of Kazakhstan, the Kyrgyz Republic, and Ukraine as court decisions ${ }^{\text {viii }}$, which are subject to appeal, means the following:

- Sentences of district and equivalent courts, specialized inter-district criminal courts, specialized inter-district military courts for minors and military garrison courts that have not entered into legal force (article 415 of the Code of Criminal Procedure);

- Court decisions of the courts of first instance that have not entered into legal force, namely sentences (except for certain court decisions in respect of which appeal specifics are provided), decisions on the use or refusal to use coercive measures of a medical or educational nature, as well as other decisions provided for in the Code of Criminal Procedure (article 392 of the Code of Criminal Procedure);

- Complaints and representations about invalid judgments and decisions rendered by a court of first instance, as well as complaints and representations about decisions of an investigating judge rendered by way of judicial control (Article 391 of the CPC of the Kyrgyz Republic).

The initiation of appeal proceedings depends on the will of the parties by filing a complaint or submitting it to the court, which considered the case on the merits. The right to appeal against a court decision belongs to: the convicted person, the acquitted person, their defenders and legal representatives, the public prosecutor and/or the higher prosecutor, the victim, the private prosecutor, their legal representatives and representatives, as well as other persons to the extent that the decision being appealed affects their rights and legal interests. A civil plaintiff, civil defendant or their legal representatives and representatives are entitled to appeal against a court decision to the extent that it concerns a civil claim (article 389.1 of the Code of Criminal Procedure, article 414 of the Code of Criminal Procedure and article 390 of the Code of Criminal Procedure, but it should be noted that the civil plaintiff, civil defendant and their representatives, as well as other persons, are not indicated).

The Code of Criminal Procedure specifies that the procurator who participated in the consideration of the case as a public prosecutor has the right to file an appeal with the procurator for a review of the court decision. An appeal by a procurator may also be lodged by the procurator-general and his or her deputies, regional procurators and equivalent procurators and their deputies, district procurators and equivalent procurators within the limits of their competence, regardless of their participation in the consideration of the case (article 414 of the Code of Criminal Procedure).

The most widely represented persons are those entitled to appeal against court decisions on appeal in Ukraine. In addition to the above-mentioned participants, the list also includes the following persons: a representative of the legal person in respect of whom the proceedings are being conducted, in the part relating to the interests of the legal person; a natural or legal person, in the part relating to his or her interests in deciding the fate of the physical evidence or documents submitted to the court; a third person, in the part relating to his or her interests in deciding on special confiscation; and other persons in the cases provided for in the Code of Criminal Procedure (art. 393).

Appeals and procurator's applications are considered by the appeals instance of the relevant provincial court and the court of equivalent status (article 416 of the Code of Criminal Procedure). These courts are not specified in the Code of Criminal Procedure.

All countries have a procedure in place for the submission of complaints and representations (petitions) by the procurator through the court that issued the court's decision as the court of first instance.

Please note the time limit for appeal: 30 days from the date of the judgment (Kyrgyzstan, art. 393 of the Code of Criminal Procedure); 30 days from the date of pronouncement of the judgment or of the ruling on the use or refusal to use coercive measures of a medical or educational nature; 
and 7 days from the date of announcement of other firstinstance court decisions (Ukraine, art. 395 of the Code of Criminal Procedure). In Kazakhstan, within 15 days of the pronouncement of the court decision (article 418 of the Code of Criminal Procedure). This period is calculated for convicted persons from the moment a copy of the court decision is served to them. The shortest time limit for appeal is 10 days from the date of the judgement or other court decision, and for convicted persons remanded in custody the same time limit from the date of delivery of copies of the judgement, ruling or decision (article 389.4 of the Code of Criminal Procedure).

The legislation of the Russian Federation, the Republic of Kazakhstan, the Kyrgyz Republic and Ukraine also provides for requirements to be met by appeals and representations (petitions). As a general rule, these are the following attributes:

Name of the court of appeal;

Data on the person who filed the complaint (representation, petition);

Indication of the court decision against which the complaint is filed (representation, petition);

arguments (claims) of the person who filed the complaint (representation, petition) and the evidence, which substantiates the claims;

A list of the materials attached to the complaint (submission, petition);

The date and signature of the author of the complaint and of the procurator (see article 389.6 of the Code of Criminal Procedure, article 423 of the Code of Criminal Procedure, article 399 of the Code of Criminal Procedure and article 396 of the Code of Criminal Procedure).

The distinctive features of the requirements for the content of a complaint (submission or petition) are the following

- In the Russian Federation, the complainant has the right to file a petition for the court of appeal to examine the evidence which has been examined by the court of first instance and to provide a list of witnesses, experts and other persons to be summoned to the court hearing for this purpose. If the evidence in question has not been examined by the court of first instance, the person must justify the impossibility of submitting the evidence to the court of first instance. The complaint of a person who is not involved in the criminal case shall specify what rights and legitimate interests of this person were violated by the court decision;

- In Kazakhstan, it is also necessary to indicate the contact details of the person who filed a complaint or brought a petition with the prosecutor (Article 423(2) of the CPC of the Republic of Kazakhstan); as well as the part of the sentence, decision or the full scope of the complaint in which the prosecutor's petition is filed (Article 423(4) of the CPC of the Republic of Kazakhstan);

- The number of the means of communication and e-mail address, if any (art. 396, para. 2, of the Code of Criminal Procedure), and the person's application for the examination of evidence (art. 396, para. 5, of the Code of Criminal Procedure) are indicated. If a person does not wish to participate in the examination, this must also be noted in the complaint. In addition, Ukrainian criminal procedure law establishes the rule that reasons must be given as to why certain circumstances were not examined in the court of first instance or why the evidence was not presented in the court of first instance. It is also noted that if the complaint is submitted by a lawyer or representative, it should be accompanied by documents confirming his authority. It is noteworthy that copies of the written materials attached to the appeal should also be provided, which are necessary to send to the parties to the criminal proceedings.

In case of non-compliance of the complaint (submission, petition) with the requirements, these documents are returned for re-writing with an indication of the term. In the Code of Criminal Procedure (art. 389.6 of the Code of Criminal Procedure) and in Kazakhstan (art. 423 of the Code of Criminal Procedure), this time limit is not specified, in Kyrgyzstan the time limit must not exceed the time limit for appealing (art. 399 of the Code of Criminal Procedure), and in Ukraine the following wording is used: "a sufficient time limit is set for their elimination (or shortcomings are caused by the author)" (art. 399 of the Code of Criminal Procedure). Thus, we can see that the legislator considers the designation of the term for reformation to be the prerogative of the court. But, as noted in the scientific studies, more than $60 \%$ of appeals, for example, in Russia, turn out to be unfounded, and their verification turns into an empty formality.

Persons who have filed an appeal (representation, petition) are also given the right to change and supplement the complaint (representation, petition). This right in the Republic of Kazakhstan and the Kyrgyz Republic must be exercised before the court session. In the Russian Federation, this term is designated as "no later than 5 days before the start of the hearing". In these countries, this includes the filing of additional appeals and submissions (petitions). It is stipulated that the additional submission (petition) of the prosecutor or his or her application for change in the prosecutor's application (in Kazakhstan), as well as the additional complaint of the victim, private prosecutor or representatives filed after the expiration of the deadline for appealing the sentence, may not raise the issue of worsening the situation of the convicted person, unless such a requirement was contained in the prosecutor's initial application or complaint. At the same time, in Kazakhstan, a defence counsel who has entered into proceedings after the expiry of the time limit for appealing a judicial act may amend or add new arguments to the complaint and provide additional arguments for the arguments of the complaint filed by the defence counsel previously involved in the case.

In Ukraine it is also possible to amend and supplement the complaint before the start of the appeal hearing. But in this case, as regulated in paragraph three of Article 403 of the Code of Criminal Procedure of Ukraine, the court of appeal, at the request of persons participating in the appeal

Published By:

Blue Eyes Intelligence Engineering

$\&$ Sciences Publication 
hearing, provides them with the time necessary to study the amended complaint and submit objections to it. In the Kyrgyz Republic, Article 398 of the CPC also provides for the right to amend or add new arguments to the complaint or representation, but no time limits are set.

The withdrawal of a complaint (submissions, petitions) is regulated as follows. In the Russian Federation, the Republic of Kazakhstan and the Kyrgyz Republic, the withdrawal may take place prior to the start of the appeal hearing. In Ukraine, however, this right may be exercised before the end of the appeal hearing.

It is necessary to pay attention to the limits of review by the court of appeal. Thus, in the Russian Federation, the court is not bound by the arguments of the complaint or representation, and may verify the case in its entirety and with respect to all persons (Article 389.19 of the Code of Criminal Procedure).

In Ukraine, according to Article 404 of the CPC, the review of court decisions is carried out within the limits of the appeal. It is permissible to go beyond the limits only if it does not worsen the situation of the accused or the person in respect of whom the issue of coercive measures of a medical or educational nature was decided. In addition, at the request of the parties to the proceedings, the court of appeal is obliged to re-examine the circumstances established in the course of criminal proceedings if they were not fully or irregularly examined by the court of first instance and if the circumstances in question were stated to have been examined at the time of the trial in the first instance, or if they became known after the decision which is being appealed against.

In Kazakhstan, this issue is regulated by Article 426 of the $\mathrm{CPC}$, according to which the court of appeal verifies the lawfulness, reasonableness and fairness of the court decision to the extent and only in respect of those convicted persons to whom the complaint or petition of the prosecutor relates. At the same time, if in the course of consideration of the case violations of the rights and lawful interests of other convicted persons resulting in a decision of an unlawful judgment or ruling are established, the court has the right to annul or amend it also in parts and in respect of persons on whom the complaint or petition of the prosecutor has not been filed, which have not been appealed against or revised upon the prosecutor's appeal. However, a sentence may only be changed or overturned in respect of persons not the subject of a complaint or petition if the sentence in question is overturned or changed in respect of the person concerned by the complaint or petition of the procurator, and only for the purpose of qualifying the actions of other convicted persons who have committed a criminal offence together.

The shortest question about the limits of appeal proceedings is regulated by the criminal procedure legislation of the Kyrgyz Republic. Under article 401 of the Code of Criminal Procedure, for example, the court of appeal verifies the lawfulness and validity of a sentence only to the extent that it has been appealed and only with respect to those convicted persons to whom the complaint or representation relates. If, however, violations of the rights and legitimate interests of other convicted persons are established in the course of consideration of the case, the court has the right to annul or amend the sentence in the part not contested and in respect of persons against whom the complaint or representation has not been filed.

It follows that despite the limitation of the limits of the scope of the appeal proceedings to the lodged complaint (submission, petition), the legislator of the countries under review allows the appeal court to go beyond the arguments of the complaint and the circle of persons who filed the complaint, if it is established that the ruling of the unlawful sentence has also violated the rights and legitimate interests of other convicts. Their situation may not deteriorate.

The following time limits have been set for the consideration of the case by the court of appeal. In the Russian Federation, the consideration of a criminal case on appeal must begin in a district court within 15 days, in the supreme court of the republic, in a regional or oblast court, in a court of federal significance, in a court of autonomous oblast, in a court of autonomous okrug, in a district (navy) military court within 30 days, and in the supreme court of the Russian Federation within 45 days of its receipt by the court of appeal (Article 389.10 of the CCrimP of Russia).

In Kyrgyzstan (article 402 of the Code of Criminal Procedure), the court of appeal must consider the case no later than two months after its receipt, and in Kazakhstan (article 425 of the Code of Criminal Procedure) no later than one month. If there are grounds for the need to examine new materials and evidence in the Kyrgyz Republic, the case must be examined no later than 3 months, and in Kazakhstan - no later than 2 months. If there are valid reasons, these terms may be extended by one month. Upon receipt of the case, the decision on the appointment of the court session must be made within 14 days from the date of receipt of the case in the appeal instance. In Kazakhstan these terms are different: the case must be considered not later than one month from the date of its receipt. Other process of preparation of appointment of appeal consideration in Ukraine: the appeal received by the court of appeal instance, not later than the next day is transferred to the judgerapporteur, who checks its compliance with the requirements within three days and in the absence of obstacles decides the decision on the opening of appeal proceedings (Article 398 of the CPC).

Then, after the opening of the appeal proceedings within ten days, the judge-rapporteur sends a copy of the decision with copies of the complaints and information on the terms of bringing objections to the participants of the trial; invites participants to submit new evidence, to which they refer or request them at the request of the person who filed the complaint; resolves other petitions, including those related to preventive measures, as well as other issues necessary for the appeal consideration.

Blue Eyes Intelligence Engineering

\& Sciences Publication

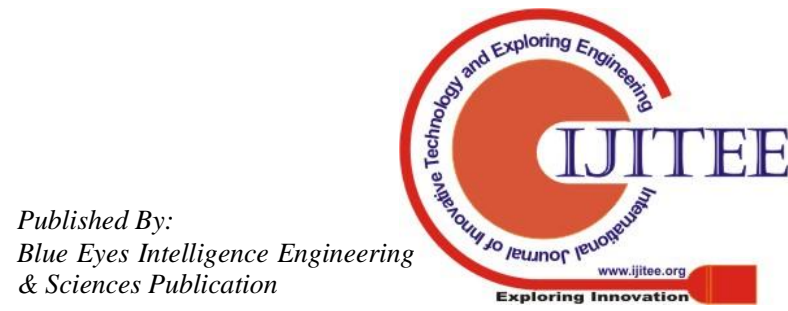


All acts and decisions are formalized by an order. After preparing for the appeal hearing, the rapporteur decides on the end of the preparation and appointment of the appeal hearing (article 401 of the Code of Criminal Procedure). Meanwhile, the terms of consideration of the CPC of Ukraine are not mentioned.

It should be noted that in the Russian Federation, one of the issues to be resolved in the ruling on the appointment of the court session is the form of participation in the court session of a convicted person held in custody: in person or through the use of videoconferencing systems.

How is the proceedings structured during the consideration of the case by the court of appeal? The procedure for consideration of a case on appeal in the Russian Federation, the Republic of Kazakhstan, the Kyrgyz Republic and Ukraine is generally similar to the procedure for consideration of a case on appeal in the Republic of Uzbekistan. Thus, the main components are the following: (1) The preparatory part of the court hearing; (2) The investigation; (3) The debate; (4) The defendant's last word; and (5) The ruling (articles 389.20 of the Code of Criminal Procedure, article 429 of the Code of Criminal Procedure, article 405 of the Code of Criminal Procedure and articles 405-406 of the Code of Criminal Procedure). The process of each country is also characterized by the presence of a judge rapporteur, who starts the proceedings by summarizing the content of the challenged court decision and the substance of the appeals (representations, petitions) filed.

At the same time, there are also some distinctive features. In the Russian Federation, evidence that has not been examined by the court of first instance (new evidence) shall be admissible if the person who filed the application for examination has substantiated that it was impossible to submit it to the court of first instance for reasons beyond his or her control, and the court finds these reasons justifiable ${ }^{\mathrm{ix}}$. It is noteworthy that, with the consent of the parties, the court of appeal has the right to consider the appeal and the submission of evidence without verification, which were examined by the court of first instance ${ }^{x}$. If the parties have not given their consent, this may lead to the annulment of the appeal decision. Cases of direct examination of evidence in the course of appeal review of criminal cases in the courts of the constituent entities of the Russian Federation occur in less than 1 per cent of criminal cases ${ }^{\mathrm{xi}}$. But even if the evidence has not been examined in court, it can be used to make a decision, as this evidence is somehow examined when the case comes in. Note that there is also the possibility of examining evidence through the use of videoconferencing systems.

The Ukrainian legislator also provides for the possibility of conducting a written appeal proceedings, if this was stated by all participants in the proceedings to conduct the proceedings in their absence. At the same time, the legislator does not rule out the possibility of an appeal hearing, if during the written proceedings the court of appeal comes to such a conclusion. In the course of the written appeal proceedings, copies of court decisions of the appeal instance shall be sent to the participants of the court proceedings within three days from the date of its signing (see Article 406 of the CCrimP of Ukraine).

In turn, in the Kyrgyz Republic, when making a decision, the court of appeal has the right to refer to the testimony of persons who were not summoned to the court of appeal, but were questioned in the court of first instance, in support of its decision. Also, with the consent of the parties, the court of appeal has the right to consider the complaint (submission) without verifying the evidence that was examined in the court of first instance (Article 405 of the CPC of the Kyrgyz Republic).

In Kazakhstan, persons submitting additional materials to the court of appeal must indicate how they were received and justify the need to complete the investigation. The additional materials cannot be obtained by means of investigative actions. It is also noteworthy that the parties may conclude a procedural agreement or an agreement on mediation conciliation (Article 429 of the CPC of the Republic of Kazakhstan) on the grounds prescribed by law when considering the case at the appeal hearing in accordance with the rules of the court of first instance.

The grounds for the annulment or amendment of a court decision in the Republic of Kazakhstan (article 433 of the Code of Criminal Procedure) and Ukraine (article 409 of the Code of Criminal Procedure) are the following: unilateralism and incompleteness of the judicial investigation; inconsistency between the court's findings set out in the court decision and the actual circumstances of the case; material violation of the law of criminal procedure improper application of the criminal law; and inconsistency between the severity of the crime and the personality of the convicted person. In the Russian Federation and the Kyrgyz Republic, the legislator did not specify such grounds as unilateralism and incompleteness of the judicial investigation. In the Russian Federation, such grounds as the identification of the circumstances referred to in part 1 and part 1 of the list are also specified. Article 237, paragraph 1, of the Code of Criminal Procedure, which requires the return of the criminal case to the procurator; the identification of evidence of a person's failure to comply with the conditions and obligations set out in the pre-trial cooperation agreement.

The criminal procedure legislation of the countries under review gives the courts of appeal the power to make the following types of decisions:

1) leaving the court decision unchanged, and the complaint (submission, petition) is not satisfied;

2) change of the court decision;

3) annulment of the court decision and termination of the case in full or in part;

4) annulment of the acquittal verdict and decision of the new acquittal or conviction; 
5) Reversal of the sentence and referral of the case to a new court (except for the appellate court in the Kyrgyz Republic).

In the Russian Federation, the appellate court may take the following decisions: to quash a conviction and impose an acquittal or conviction; to quash an acquittal and impose an acquittal; to quash a determination or judgment and impose an acquittal or other judgment; to quash a conviction, determination, judgment and return the case to the prosecutor; and to terminate appeal proceedings. A verdict, ruling, or ruling of the court of appeal may be appealed to a higher court in accordance with the procedure established by Chapter 471 (in the cassation procedure) and 481 of the CCrimP of Russia (in the supervisory procedure).

In addition, in Kazakhstan, when significant violations of the criminal procedure law are established that prevent the appointment of the main court proceeding, or when such violations are established in the course of proceedings in cases of accelerated pre-trial proceedings or with a signed procedural agreement, the court of appeal quashes the sentence and forwards the case to the prosecutor (Article 431 of the CPC of the Republic of Kazakhstan).

There are also specific features of the annulment of an acquittal: in Ukraine (article 409 of the Code of Criminal Procedure), the court of appeal may annul the acquittal verdict only on the grounds of a material violation of the rights of the accused; in Kazakhstan, the acquittal verdict may be annulled only at the request of the procurator or at the request of the victim or his or her representative, or of an acquitted person who disagrees with the grounds for acquittal (article 440 of the Code of Criminal Procedure). An acquittal in favour of the defendant may not be overturned on the grounds of the material breach set out in article 436 of the Code of Criminal Procedure, unless the innocence of the acquitted person, the grounds for acquittal or the essence of another decision in favour of the defendant are disputed.

It should be noted that the Russian Federation's scientific research identifies excessive workload as one of the problems affecting the effectiveness of appeal proceedings, since appeal proceedings are conducted in more than one third of criminal cases. A study of the opinion of judges involved in appeal proceedings suggests that the system has reached its limits, even having moved to a "quasi-appeal" mode of operation ${ }^{\text {xii }}$. As noted by M.V. Sklyarenko, the current stage of development of the system of appeal, verification and review of court decisions in the criminal process is also characterized by the lack of a loyal environment, if not hostility; the main thing here is the lack of understanding of the fact that the capacity of the system of appeal, verification and review of court decisions in the criminal process is overloaded ${ }^{\text {xiii }}$ at a particular time period is largely determined by the level of conflict in the criminal process ${ }^{\mathrm{xiv}}$.

The next type of review of court decisions is cassation proceedings, which are aimed at verifying the effective court decisions of the first and appellate instances. The purpose of these proceedings is to identify the factual and legal errors committed by the courts of first instance and appeal courts in the consideration and settlement of criminal cases; to take decisions by the court of cassation, within the limits of its jurisdiction, to remedy the errors identified through the annulment or amendment of the judicial acts being reviewed; and to restore the validity of judicial decisions ${ }^{\mathrm{xv}}$. Scientific publications note that the reform of verification proceedings, including cassation proceedings, carried out in the Russian Federation in 2010 was aimed at quickly identifying and eliminating errors in the application of criminal procedure and criminal law contained in the sentence, accelerating criminal proceedings, and ensuring the steadfastness and stability of court sentences ${ }^{x v i}$. For example, this has been achieved by excluding the transfer of the case from appeal to another appeal instance ${ }^{\text {xvii }}$, which significantly reduced the time frame for criminal proceedings. In turn, the subject matter of the cassation proceedings was also limited to checking only the legality of the court decision. All these measures have been taken with the aim of achieving legal certainty and stability of court decisions

Among the peculiarities of cassation proceedings are the following: freedom of appeal; a combination of verification of legality, validity and fairness of the sentence; limited limits of consideration of the case by the court of cassation instance by the subject of the complaint or submission (in the form of a general rule); the possibility of using additional materials and examination of evidence; the prohibition to turn to the worst for the convicted or acquitted person $^{\text {xviii }}$.

In the Russian Federation, unlike on appeal, appeals and representations are filed directly with the court competent to consider the appealed court decision in cassation. In doing so, the requirements of the courts of law are observed. That is, the complaint and submissions are considered first in the lower court of cassation instance, and then in the higher court. It should be noted that this decision of the legislator to establish two cassation instances is criticized by the scientific community. Thus, M.K.Sviridov believes that it is difficult to explain why the law allows verification of the actual side of the sentences only once, while the cassation of their legality - at least twice, and in case of cancellation of the higher cassation instance of the sentence and sending the case to the lower cassation instance (such law allows) several times ${ }^{\text {xix }}$. I. S. Dikarev, on the contrary, believes that "this step of the legislator is conditioned by the desire to ensure the implementation of the principle of legal certainty in criminal proceedings, to create for him reliable guarantees preventing the challenge of the correctness of the establishment of the facts of the case after the entry into force of the decision". ${ }^{\mathrm{xx}}$. 

decision of the Russian legislator can be justified in terms of seeking to achieve legal stability in the decisions made, At the same time, the establishment of the possibility of increasing the checks of judicial decisions by means of cassation is, in our view, at the initial stage a necessary element for the elimination of judicial errors, before instilling in the participants of the criminal process the awareness of the impossibility to do so in the future by virtue of their failure to exercise their right to appeal in a timely and qualitative manner. In this regard, we join M.K.Sviridov in his opinion that the main means of correcting "ordinary" mistakes should be the appellate instance, when the sentence has not yet entered into legal force, but in the future, after the entry into legal force of the sentence, the issue of ensuring the stability of the sentence as a necessary condition for its certainty comes to the fore ${ }^{\mathrm{xxi}}$. Moreover, some procestualists believe that the basis for the successful consideration of a criminal case, along with the development by the parties of a legal position adequate to the factual circumstances established in the criminal case in the consideration of a criminal case in court, and the solution of the issue such as the definition of the obligation of the parties to timely appeal against illegal court decisions on appeal $^{\mathrm{xxii}}$.

The cassation instance in the Republic of Kazakhstan, the Kyrgyz Republic and Ukraine is the Supreme Court. Court judgments of the first instance court may be appealed against in cassation procedure after they have been considered on appeal, as well as court judgments of the court of appeal made on the basis of the said court judgments of the first instance. Kazakh criminal procedure legislation contains a number of restrictions on judicial acts that are not subject to cassation review. According to article 484 of the Code of Criminal Procedure, these are acts in cases of criminal offences and crimes of minor gravity. These acts may be reviewed in cassation only upon appeal by the Procurator-General of the Republic of Kazakhstan if there are grounds specified in article 485 of the Code of Criminal Procedure of the Republic of Kazakhstan and upon submission by the Chairman of the Supreme Court and appeal by the Procurator-General of the Republic of Kazakhstan if there are grounds provided for in paragraph two of article 485 of the Code of Criminal Procedure of the Republic of Kazakhstan. Also, court decisions made in the course of the court proceedings on the issues specified in the second part of Article 10 of the CPC may not be the subject of cassation consideration ${ }^{x x i i i}$; regarding the procedure and method of examination of evidence, petitions of the participants in the proceedings, observance of the procedure in the courtroom in connection with the refusal to accuse the public and private prosecutor, on issues related to the execution of the sentence, as well as issued by the investigating judge (Article 484 of the CPC of the Republic of Kazakhstan). In Ukraine, the legislator stipulates that decisions of the court of first instance, after their review on appeal, as well as decisions of the court of appeal may be appealed against in cassation, if they hinder further criminal proceedings, except in cases provided for in the Code of Criminal Procedure (article 424 of the Code of Criminal
In our opinion, the truth is in the middle. Indeed, the

Procedure). Objections to other rulings may be included in a cassation appeal against a court decision taken on appeal.

The subjects of the appeal and appeal include all the parties entitled to appeal and challenge (article 401.2 of the Code of Criminal Procedure, article 425 of the Code of Criminal Procedure, article 431 of the Code of Criminal Procedure and article 486 of the Code of Criminal Procedure). The Russian Federation Code of Criminal Procedure explains that the following may apply to any court of cassation for a review of a court decision that has entered into force: the Procurator-General and his or her deputies; the Procurator-General of a constituent entity of the Russian Federation, a military procurator and their deputies may apply to the presidium of the Supreme Court of the Republic, a regional or oblast court, a federal court, an autonomous oblast court, a court of an autonomous okrug or a district (navy) military court, respectively.

There is no time limit for the review of court decisions on grounds improving the situation of a convicted person. Thus, in the Russian Federation, the cassation review of a sentence, ruling, or ruling of a court on the grounds leading to the deterioration of the situation of a convicted person, acquitted person, or a person against whom a criminal case has been terminated, is allowed within a period not exceeding one year from the date on which they came into force, if in the course of the judicial proceedings violations of the law that have affected the outcome of the case, distorting the essence of justice and the meaning of the judicial decision as an act of justice have been admitted, or if data have been found to indicate that the person has failed to comply with the conditions and is not satisfied? In Kazakhstan, the revision of a sentence on the grounds leading to an improvement in the situation of a convicted person is not limited in time; the submission of an application, protest, proposal to revise an acquittal, a guilty verdict on the grounds of the need to apply the law on a more serious criminal offence, for the leniency of the sentence or on other grounds leading to a deterioration in the situation of the convicted person, or a court decision on the termination of the case, is allowed within one year after the entry into force of the law (Article 487 of the CPC of the Republic of Kazakhstan). In the Kyrgyz Republic, the cassation review of a sentence or a ruling of the court of appeal is limited only on the grounds that lead to a worsening of the situation of the convicted person, the acquitted person or the person in respect of whom the cases have been dismissed. Such review is permitted within a period not exceeding one year from the date on which the court decision enters into force (article 433 of the Code of Criminal Procedure). A slightly different approach in Ukraine. Under article 437 of the Code of Criminal Procedure, the court of cassation is not empowered to apply the law on the more serious criminal offence or the severe penalty.

Published By 
A guilty verdict adopted by a court of first instance or an appeal court or a ruling of a court of first instance may be quashed for reasons of the need to apply the law on a more serious criminal offence or severe punishment or otherwise worsen the situation of the convicted person only if the appeal was lodged on these grounds by the procurator, the victim or his or her representative. No time limits are specified.

The requirements for a cassation appeal (protest, petition or representation) in Ukraine are virtually identical to those for an appeal (article 427 of the Code of Criminal Procedure). Similarly, the issue was resolved in the Kyrgyz Republic, with the only added point being the need to refer to the courts that examined the case at first instance and appeal instance and the content of their decisions (Article 435 of the CPC of the Kyrgyz Republic). In Kazakhstan, in addition to the circumstances that must be specified in the appeal or protest, there must also be specified which violations of the law were committed during the proceedings and how these violations affected the court decisions rendered, and which of the court decisions listed in Article 485 of the CPC (grounds for cassation review of court judgments and decisions that have entered into force) there are grounds for revising the judicial act under appeal. The application must indicate whether or not they have been examined by the persons who filed them (article 488 of the Code of Criminal Procedure). It should be noted that in Kazakhstan, an application, protest and application for review of judicial acts that have entered into force may be submitted not only in writing, but also in the form of an electronic document. In the Russian Federation, the legislator has established that the complaint and submission must be accompanied by copies of court decisions certified by the relevant court, as well as other documents. Complaints and representations corresponding to requirements are studied by judges and in case of need the judge can demand a criminal case. By results of studying the judge can make the decision in the form of the decision or about refusal in transfer of the cassation appeal, representation for consideration in court of cassation instance (if are absent for this basis), or about transfer of the cassation appeal, representation with criminal case for consideration in court of cassation instance. It is noteworthy that this judge is not entitled to participate in the examination of the criminal case.

It should be noted that a distinctive feature of cassation proceedings in the Republic of Kazakhstan is the existence of a stage of preliminary consideration of an application for review of judicial acts that have come into force. Thus, within 10 days the cassation judge must resolve the issues: (1) Whether or not there are grounds for returning the application on the grounds set out in the Code of Criminal Procedure; and (2) Whether or not there are grounds for requesting a court case (article 490 of the Code of Criminal Procedure). Prior to the preliminary consideration of the application, the judge may also instruct the relevant specialists to prepare a scientific opinion on the rules of law applied in the criminal case under consideration. Where necessary, specialists may give explanations at a session of the cassation court panel.

In its turn, Ukraine also knows the stage of preparation of the cassation hearing, where the judge-rapporteur takes measures to prepare the proceedings for the cassation hearing (Article 430 of the CPC of Ukraine). All decisions taken are set out in the form of a decision (such as sending a copy of the ruling on the opening of cassation proceedings with copies of the complaints to the parties to the proceedings; requesting the materials of the criminal proceedings; resolving the petitions submitted; and deciding on the suspension of execution of court decisions, which are appealed against, and others).

The right to withdraw a complaint (petition, representation or protest) may be exercised as follows: in Kazakhstan (article 488 of the Code of Criminal Procedure) prior to the consideration of the case in cassation instance; in Ukraine (article 432 of the Code of Criminal Procedure) prior to the end of the cassation proceedings; and in Kyrgyzstan (article 436 of the Code of Criminal Procedure) prior to the removal of judges to the jury room.

The question arises as to the limits of the appeal court's consideration. In the Russian Federation, for example, the court of cassation is not bound by the arguments of the complaints and representations and has the right to inspect the criminal proceedings in their entirety, and in respect of all convicted persons. It is noteworthy that in the event that several persons have been convicted or acquitted in a criminal case, the court is not entitled to annul the verdict, ruling or ruling in respect of those acquitted or convicted in respect of whom a cassation appeal or representation has not been brought, if the annulment of the verdict, ruling or ruling worsens their situation (Article 401.16 of the CCrimP of Russia). In the event of the annulment of a court decision, the court of cassation is not entitled to do so: 2) prejudge questions of proving or not proving the accusation, reliability or inaccuracy of one or another evidence and the advantages of one evidence over another; 3) make decisions on the application of a criminal law and on the measure of punishment by a court of first or appellate instance; 4) prejudge conclusions that may be made by a court of first or appellate instance when reconsidering a given criminal case $^{\mathrm{xxiv}}$.

In Kazakhstan, the court examines the lawfulness, reasonableness and fairness of the judgment in its entirety. Amendments may be made to the judicial act on the grounds not specified in the petition, in the protest, as well as with respect to other convicted persons in respect of whom the petition or protest has not been filed, only in the event of a change in the qualification of the crime committed in complicity with the convicted person in respect of whom the petition has been filed, unless their situation deteriorates. 
The court has the right to make a decision on aggravation of the situation only with respect to those convicted persons, about whom it is indicated in the prosecutor's protest or petition. At the request of a convicted person or his or her counsel, the court may not worsen the situation of the convicted person (article 494 of the Code of Criminal Procedure).

In the Kyrgyz Republic, the cassation court is not bound by the arguments of the cassation appeals or representations and has the right to review the proceedings in respect of significant violations of substantive and procedural law, as well as in respect of all convicted persons, even if they have not filed a complaint or representations. At the same time, in cases where more than one person has been convicted or acquitted, the court may not overturn a conviction or ruling in respect of those acquitted or convicted in respect of whom a cassation appeal or representation has not been brought, if the verdict has been overturned, the ruling worsens their situation (Article 432 of the CPC of the Kyrgyz Republic).

In Ukraine, the court of cassation verifies the correct application by the courts of first instance and appeal courts of the rules of substantive and procedural law, legal assessment of evidence and has no right to examine the evidence, establish and recognize as proven the circumstances that were not established in the challenged court decision, and decide on the reliability of any evidence. The review is carried out within the scope of the appeal. The court of cassation has the right to go beyond the limits of the cassation requirements, unless the situation of the convicted person, the acquitted person or the person in respect of whom the issue of the use of coercive medical or educational measures was decided. If the satisfaction of the complaint gives rise to a decision in favour of the other convicted persons from whom the complaint was received, the court of cassation is obliged to take such a decision (article 433 of the Code of Criminal Procedure).

The procedure for consideration of cases in the cassation instance in the Russian Federation, Kazakhstan, Kyrgyzstan and Ukraine is carried out in accordance with the rules for consideration in the court of appeal. In Ukraine, the court of cassation may also take a decision on the basis of the results of the written proceedings if all the parties to the proceedings so request (article 435 of the Code of Criminal Procedure).

The grounds for the annulment or amendment of court decisions in cassation proceedings in the Russian Federation are substantial violations of criminal and/or criminal procedure law that have affected the outcome of the case, or the identification of data indicating a person's failure to comply with the conditions and obligations provided for in the pre-trial cooperation agreement (Article 401.15 of the CCrimP of Russia). In Kazakhstan, the grounds are the same as in the appeal procedure (article 494 of the Code of Criminal Procedure). The grounds for quashing and amending a sentence in the Kyrgyz Republic are set out in article 432 of the Code of Criminal Procedure, which regulates the limits of the rights of the cassation court and, as such, refers to significant violations of substantive law and procedural law. Such grounds include a material breach of the requirements of the Code of Criminal Procedure, improper application of the Criminal Liability Act and the incompatibility of the sentence with the gravity of the criminal offence and the personality of the convicted person (article 438 of the Code of Criminal Procedure).

Among the powers of the cassation authorities, the following are specified as a result of the review: (1) maintain in force (unchanged) the decision being appealed against (in the Russian Federation, Kazakhstan, the Kyrgyz Republic and Ukraine); (2) amend the court decision (in the Russian Federation, Kazakhstan and Ukraine); (3) annul the verdict and other subsequent decisions and terminate the case (in the Russian Federation, Kazakhstan, Ukraine and the Kyrgyz Republic); (4) annul the verdict and all other subsequent decisions and refer the case for a new court of appeal or cassation (in Kazakhstan and Ukraine). In the Kyrgyz Republic, if there is a violation of procedural law or an error in the application of substantive law, the decision is made without referring the case for reconsideration); 5) to overturn the decisions made on appeal and cassation, changing the court's sentence or leaving it unchanged (in Kazakhstan); 6) to leave in force one of the acts made (the Kyrgyz Republic). The Russian Federation also provides for decisions such as: to annul the judgment, ruling or ruling of the court and all subsequent court decisions and to transfer the criminal case for a new trial or to return the case to the prosecutor; to annul the judgment of the court of appeal and to transfer the criminal case to a new appeal

Another type of judicial review, which to date has remained among the studied countries only in the Russian Federation, is supervisory review proceedings, in which the Presidium of the Supreme Court of the Russian Federation considers, as a supervisory procedure, criminal cases on complaints and submissions regarding the legality of court decisions that have come into force. This check is carried out in order to correct legal errors ${ }^{\mathrm{xxv}}$. This check depends on the discretion of the persons defined by law. The subject matter of the audit may be both the decisions of the court of first instance and the decisions of the courts of appeal and cassation

Participants in supervisory review proceedings include the following: participants vested with the right to apply for the review of court decisions that have come into force; the supervisory-instance court; and other persons whose rights and legitimate interests are affected by the supervisory appeal or representation.

An appeal or representation shall be filed directly with the supervisory-instance court, i.e. with the Supreme Court of the Russian Federation. Compliant supervisory appeals and representations shall be examined by a judge of the Supreme 
Court both on the basis of the materials attached thereto and on the basis of the criminal case file requested. Based on the results of the study, the judge may make the same decisions as when examining a cassation appeal or representation.

A supervisory appeal or representation must be considered within one month, and in the event of a criminal case being requested, within two months of its receipt.

In the event of a refusal to consider the case under the supervisory procedure, the decision must also state the reasons for the refusal.

Similar to cassation proceedings, a judge who has studied a supervisory appeal or representation may not take part in the consideration of a given criminal case by the Presidium of the Supreme Court of the Russian Federation. The participation of a prosecutor is mandatory.

It should be noted that the Russian Federation is also engaged in a heated debate on the need to reform the system for reviewing court decisions and ways of correcting judicial errors. Thus, in the opinion of M.K.Sviridov, it seems to be sufficient to have two verification instances in the criminal process: ordinary - appeal and exceptional - renewal of cases on newly discovered circumstances ${ }^{\text {xxvi }}$.

In turn, the European Court of Human Rights has repeatedly stated that cassation and supervisory proceedings in Russia are not effective forms of protection of individual rights in criminal proceedings in the context of international legal standards ${ }^{\text {xxvii }}$. O.A. Sukhova also notes that international standards in principle dictate that the cassation procedure of verification should be such that final court decisions would be checked only once in cassation and in one cassation instance xxviii. This is also noted by N.P. Vedishchev, who believes that Russian supervisory proceedings cannot be an effective remedy due to the fact that they violate the internationally recognized principles of inadmissibility of re-examination of a once decided case and legal (legal) certainty, in which the final decision on the case should not be questioned ${ }^{\text {xxix }}$.

Resumption of criminal proceedings in view of new or newly discovered circumstances ${ }^{x x x}$. Despite some differentiation in the name, each of the surveyed countries in the criminal procedure legislation provides for such a way of verifying court decisions and correcting judicial errors, which is the second (after the proceedings in the supervisory-instance court) special, exclusive stage of the criminal procedure, within which it is also possible to review the effective judgments, definitions and decisions of all courts and all courts, and is a "reserve mechanism" to eliminate judicial errors ${ }^{\mathrm{xxx}}$. According to N.P.Vedishchev, "the resumption of criminal proceedings in view of new or newly discovered circumstances in the criminal justice system acts simultaneously as an exceptional stage of criminal procedure and as one of the forms of proceedings to verify court decisions". ${ }^{x x i i}$. This opinion cannot be completely separated, as we believe that the content of the stage of criminal proceedings is the actual proceedings, i.e. in the case under consideration one of the forms of proceedings to verify court decisions. Therefore, the concepts of "stage" and "form of proceedings" in this definition have the same purpose.

In some scientific publications it is noted that during the period of validity of the last Soviet Code of Criminal Procedure the procedure of revision of judicial acts due to the newly discovered circumstances in the practice of law enforcement was very rarely used for such reasons as: (1) In the practice of reviewing judicial acts that have entered into force, the "simpler" institution of supervisory review dominated, which often replaced the procedure for resuming criminal proceedings; (2) the question of reviewing a judicial act entirely depended on the discretionary powers of the prosecutor, whose decision not to initiate a judicial review procedure could be appealed only to a higher prosecutor and was not subject to judicial review ${ }^{\text {xxiii }}$. In reforming the institution of judicial review, one of the positive decisions was the establishment of judicial control over the actions and decisions of the prosecutor taken on the basis of the results of the pre-trial review of reports on the existence of grounds for reviewing a judicial act, as well as by including the decisions of the Constitutional Court of the Russian Federation and the decisions of the European Court of Human Rights among the grounds entailing the resumption of criminal proceedings.

Speaking about the exclusivity of the stage in the system of institutions for the revision of court decisions in the Russian Federation, in our opinion, it should be noted that this exclusivity is due to the following circumstances: first, the rule of institutionality is not observed, i.e. this proceeding may take place both after the consideration of the case in court and after the consideration in the court of cassation or supervisory instance; second, only the prosecutor may initiate such proceedings, and this, in turn, means a violation of the principle of adversariality; third, it is established All these circumstances determine the exclusivity of this stage of judicial review, which arises in connection with the discovery of new, unknown circumstances in the investigation and consideration of the case, establishing their illegality and unreasonableness. In our opinion, the exclusiveness of this proceeding was also facilitated by the following circumstance. According to N.P.Vedishchev: "Until now, it is not always possible to draw a distinction between the cases when the court's decision, which has come into force, should be revised by resuming the proceedings, and the cases when - by way of supervisory proceedings; the grounds for resuming the case remain unclear for the law enforcement officer in view of the newly discovered and, especially, new circumstances, the procedural status of the convicted person (acquitted and the person in respect of whom the case was terminated) in the investigated stage of the criminal process, the legal mechanism $^{\text {xxxiv }}$. 
Resumption of criminal proceedings in the Russian Federation in view of new or newly discovered circumstances as a type of procedural activity can be divided into three stages: initiation of proceedings by the prosecutor in view of new or newly discovered circumstances; conduction of special investigation or inspection in order to establish these circumstances; resolution by the court of questions on resumption (or refusal to resume) of proceedings in the criminal case ${ }^{\mathrm{xxxv}}$.

The grounds for resuming criminal proceedings are as follows:

(1) Knowingly established by a court verdict that the testimony of the victim or witness, the opinion of an expert, as well as the falsification of physical evidence, investigation and court records and other documents, or knowingly mistranslation, resulting in a decision of an illegal or unjustified court decision, are false (the Russian Federation, Kazakhstan, the Kyrgyz Republic and Ukraine);

2) criminal actions of the person conducting the initial inquiry, investigator or prosecutor, which resulted in the decision of an illegal and unjustified court decision, established by a court sentence which has come into force (the Russian Federation, Kazakhstan, the Kyrgyz Republic and Ukraine);

(3) Criminal acts committed by judges in the course of their consideration of the case, as established by a verdict of a court that has entered into force (the Russian Federation, Kazakhstan, the Kyrgyz Republic and Ukraine);

(4) Circumstances unknown to the court at the time of the delivery of the court decision, which, by themselves or together with previously established circumstances, attest to the innocence of the convicted person or to the commission of an offence other than the one for which he or she was convicted, or to the guilt of the acquitted person or of the person in respect of whom the case was terminated (Kazakhstan, the Kyrgyz Republic and Ukraine);

(5) Recognition by the relevant authority of an unconstitutional law or other normative legal act that was applied by the court when it issued the judicial act (the Russian Federation, Kazakhstan, the Kyrgyz Republic and Ukraine);

(6) Exemption from criminal liability for the offence giving rise to the confiscation on the basis of an enforceable acquittal of a court decision or an order terminating the criminal proceedings for lack of the event or composition of the criminal offence, or the partial or total non-application of the confiscation of property in the judgement of the court that considered the case on the merits (Kazakhstan);

7) the will of the convicted person in respect of whom the case was examined in his or her absence ${ }^{\text {xxxi }}$, In case of his appearance in the body conducting the criminal proceedings (Kazakhstan);

8) Circumstances related to the review of the sentence imposed on the accused with whom a cooperation agreement has been concluded (Kyrgyz Republic);

(9) The determination by international bodies, in accordance with international agreements to which Kyrgyzstan is a party, of violations of human rights and freedoms during the consideration of a given criminal case by a court of law (Kyrgyzstan). In Ukraine, an international

judicial institution whose jurisdiction is recognized by Ukraine establishes that Ukraine is in breach of its international obligations in the determination of the case by the court;

(10) The annulment of the court's decision, which was the basis for the verdict or ruling (Ukraine);

(11) A violation of the provisions of the Convention for the Protection of Human Rights and Fundamental Freedoms by the European Court of Human Rights in a criminal case involving: (a) the application of federal law that is not in conformity with the provisions of the Convention for the Protection of Human Rights and Fundamental Freedoms; (b) other violations of the provisions of the Convention for the Protection of Human Rights and Fundamental Freedoms; or (c) the occurrence, during the period in which the criminal case is being considered by the court or following the issuance of a court decision, of new socially dangerous consequences of the alleged offence

In the Russian Federation, based on the results of consideration of the prosecutor's opinion on the resumption of criminal proceedings in view of new or newly discovered circumstances, the court may take the following decisions: 1) to annul the judicial act and transfer the criminal case for a new trial (in agreement with the prosecutor's arguments); 2) to annul the judicial act and all subsequent judicial decisions and return the criminal case to the prosecutor in case of identification of the circumstances specified in the Criminal Procedural Code of the Russian Federation (related to various violations of the law);

3) to Despite the reform of the institution of resumption of criminal proceedings, some researchers in the Russian law enforcement practice note a number of problems that arise in the application of this method of correction of judicial errors. Thus, V.A. Davydov cites the following miscalculations: 1) in the regulation of the procedure of pretrial verification proceedings carried out by the prosecutor, including the investigation of the so-called "other" new circumstances; 2) in the regulation (more precisely, in the absence of such) of procedural activities of the Chairman of the Supreme Court of the Russian Federation related to the initiation of verification proceedings in connection with the decisions of the Constitutional Court of the Russian Federation and the European Court of Human Rights; 3) in the regulation: a) the system of courts competent to review a judicial act in view of new or newly discovered circumstances; b) the limits of the rights of the court; c) the types of court decisions and the procedure for their appeal and review; d) the judicial procedure for consideration of the criminal case itself, as advised by the Chairman of the Supreme Court of the Russian Federation or upon the conclusion of the prosecutor; e) the specifics of proceedings in a criminal case after the annulment of judicial acts in view of new or newly discovered circumstances ${ }^{\text {xxxvii }}$

The right to file an application (petition) for the initiation of proceedings under newly discovered circumstances belongs to: 
- A convicted person, an acquitted person, a victim or their legal representatives, defence counsel or a procurator (article 502 of the Code of Criminal Procedure and article 445 of the Code of Criminal Procedure);

- Participants in court proceedings (Ukraine).

The application (petition) is submitted to the court that issued the judgement. This rule differs in the Ukrainian criminal procedure legislation, which establishes the procedure depending on the grounds for resuming the proceedings: an application on newly discovered circumstances is submitted to the court of the instance, which was the first to make a mistake due to ignorance of the existence of such circumstances; an application for reconsideration due to exceptional circumstances in the case of a crime committed by a judge, as a result of which an illegal or unjustified decision was made, is submitted to the court of the instance, the judge of which he or she was the first to make the application.

The terms for resuming proceedings are as follows:

- the revision of the guilty verdict in view of new or newly discovered circumstances in favor of the convicted person is not limited by any period of time; the revision of the acquittal verdict, or the ruling, decision on termination of the criminal case, or the guilty verdict due to the leniency of the sentence or the need to apply to the convicted person the criminal law on a more serious crime is allowed only within the limitation period established by the Criminal Code of the Russian Federation and not later than one year from the date of opening

- The review of the acquittal verdict, the decision to dismiss the case, and the review of the guilty verdict on grounds that worsen the situation of the convicted person are permitted only within the time limits for bringing the person to criminal liability and not later than one year from the date of discovery of the new circumstances (article 501 of the Code of Criminal Procedure of the Republic of Kazakhstan);

- The revision of the guilty verdict in favour of the convicted person is not limited by any period of time, the revision of the acquittal verdict, the ruling, the decision on termination of the case, as well as the revision of the guilty verdict due to the leniency of the sentence or the need to requalify the act in the direction of aggravation are allowed only during the period of limitation for bringing to responsibility for the crime or misdemeanour, but not later than one year from the date of discovery of new or newly discovered circumstances (Article 444 of the CPC of the Kyrgyz Republic);

- An application for review of a court decision on newly discovered circumstances may be submitted within three months after the person who applies to the court learned or could have learned about these circumstances; a review of an acquittal judgment on newly discovered circumstances is permitted only within the statutory time limits for bringing a person to criminal liability; in the presence of circumstances confirming that the person has committed a more serious criminal offence than the one for which he or she was convicted, the court decision In addition, the Ukrainian legislator shall specify the terms of submission of the application depending on the grounds for resumption of proceedings.
Requirements to the application for revision of the court decision, as well as the rules of its rejection ${ }^{\text {xxviii }}$, Regulates only the Code of Criminal Procedure (arts. 462 and 465 of the Code of Criminal Procedure)

If necessary, the materials may be sent to the prosecutor to verify or investigate whether there are grounds for resuming proceedings (Articles 502-503 of the CPC of Kazakhstan). If the grounds are established, the application with the materials is sent to the court, otherwise the prosecutor refuses to initiate proceedings by his or her reasoned decision, which may be appealed to a higher prosecutor. This, as well as the right to apply to the court with a request to initiate proceedings, is explained to the applicant.

The Code of Criminal Procedure also establishes the procedure for consideration by the court of an application to reopen proceedings on newly discovered facts (article 504 of the Code of Criminal Procedure). The application is considered by a single judge of the court of first instance. If, however, the courts of appeal and cassation have ruled on the case, the courts of appeal and cassation will review the decisions of those courts. The applicant, his or her representative, counsel, prosecutor and other participants and persons summoned to the hearing are entitled to participate in the proceedings. In this case, the absence of duly notified persons does not prevent the consideration of the application. The court may also oblige such participation. The issue of participation of persons in the court hearing and in the CPC of Ukraine has also been resolved (Article 466 of the CPC).

Based on the results of the proceedings on newly discovered circumstances, the following decisions may be taken:

- satisfaction of the petition (application) and annulment of the court decision and transfer to the prosecutor for pretrial proceedings or to the court for a new trial; satisfaction of the petition and annulment of the court decision, termination of the case, when no new pre-trial proceedings or new trial is required to make a final decision on the case; refusal to satisfy the petition (Article 446 of the CPC of the Kyrgyz Republic);

- annulment of a court decision and ruling of a new judgment or ruling, or leaving an application for reconsideration without satisfaction; annulment of a court decision in whole or in part and transfer of the case for a new court hearing to a court of first instance or appeal instance (Article 467 of the CPC of Ukraine);

- Granting the application and cancelling the relevant judicial act and sending the case for a new investigation or consideration; or discontinuing the proceedings if the investigation and consideration is not required (Article 505 of the CPC of Kazakhstan); upon consideration of the prosecutor's application, the court may grant the application and annul the judgment or ruling of the court and refer the case for investigation or a new trial; grant the application and annul the judgment or ruling of the court and terminate the case if the investigation or judicial review is not required

Published By: 


\section{(Article 505 of the CPC of Kazakhstan)}

Is it possible to appeal against decisions taken as a result of newly discovered circumstances? In Ukraine, these decisions can be appealed against in the manner prescribed by the criminal procedure legislation for appealing against court decisions of the respective instance. In the Kyrgyz Republic, appeals against new court decisions are also made in the general order (Article 447 of the CPC of the Kyrgyz Republic).

Otherwise, the Republic of Kazakhstan went on to establish that the decisions of the court of first instance and the court of appeal, made on the basis of the results of consideration of the application for resumption of proceedings on newly discovered circumstances may be appealed and contested. A resolution rendered by the Supreme Court of the Republic of Kazakhstan shall not be subject to appeal or protest and shall come into force from the moment of its pronouncement. The ruling of a higher court on leaving the appealed ruling unchanged, annulled or changed is final and not subject to further appeal (Article 505 of the CPC of Kazakhstan). Decisions of the court of first instance and appeal instance made on the basis of the results of consideration of an application on newly discovered circumstances may be appealed against by the prosecutor or by protests. They are heard by a higher court in the manner prescribed for the consideration of appeals, cassation appeals, procurator's applications and protests. A decision of a higher court to uphold, annul or amend an appealed decision is final and subject to further appeal or review at the request of the public procurator (article 507 of the Code of Criminal Procedure)

Analysis of the legislation of the CIS countries in the area of revision of court decisions in criminal proceedings as a means of correcting judicial mistakes, and the position of scientists in this area as applied to the legislation of the Republic of Uzbekistan allows to draw the following conclusions

\section{RESULTS \& DISCUSSIONS}

The current procedure for the review of court decisions in Uzbekistan's criminal proceedings does not fully contribute to the timely detection and correction of judicial errors and does not ensure the legal certainty or finality of court decisions. As a result, court sentences are reviewed several times, sometimes four to five times. Sometimes sentences are overturned or changed by the supervisory-review court several years after they come into force. There are cases of review of court decisions after 10-15 years after the entry into force of the sentence. On 5 March 2008, I. Y. was convicted by the Samarkand provincial criminal court under article 97, paragraph $2(\mathrm{k})$, of 18 years' deprivation of liberty. The ruling of the court of cassation of 15 March 2012 left the sentence unchanged. The Supreme Court dismissed repeated supervisory appeals by the convicted person and his or her defence counsel. It was only in 2019 that the decision of the Judicial Collegium for Criminal Cases of the Supreme Court, which considered the case under the supervisory procedure, changed the court decisions in the case, and the actions of the convicted person were reclassified to the first part of Article 97 of the Criminal Code. ${ }^{\text {xxix }}$.

Another case. The verdict of Mirzo court of Ulugbek district on criminal cases of November 2, 2012 against B.Z., convicted under paragraph "c" of part four of Article 166 of the Criminal Code, the sentence of Navoi Regional Criminal Court of August 22, 2014 against S., convicted under paragraph "b" of part two of Article 97 of the Criminal Code, was also changed after repeated appeal by the Judicial Collegium on Criminal Cases of the Supreme Court only in $2019^{x 1}$.

Endless review of the legality and validity of court decisions does not contribute to their stability and uniformity of judicial practice. This, in turn, enables the parties to criminal proceedings to abuse the right to appeal against court decisions, which, by appealing to each court, bring new and new arguments and new evidence in complaints, without providing them in a timely manner, and thus delaying the resolution of the issue.

\section{CONCLUSIONS}

The following conclusions can be drawn from the analysis of the system of ways to review court decisions in foreign countries:

1. The existence of a number of instances and methods of judicial review cannot, in itself, guarantee a qualitative review and effective correction of judicial errors.

2. A condition for a case to be heard in higher courts is a complaint (submission, petition, protest):

- Different procedural regulations for the review of court decisions are provided, depending on the method of review;

- Differentiated requirements for remedies (e.g. in the Russian Federation);

- There is a different range of subjects who have the right to initiate a review of court decisions, depending on the method of review, as well as the procedural position occupied;

- Establishing limits on the review of court decisions depending on the subject matter of the appeal and indicating the arguments in respect of factual and procedural issues and in respect of the respective persons whose interests were affected by the court decision; as well as restricting the scope of the review in the activities of the higher court.

3. In order to improve the institution of judicial review, it would be advisable to implement some positive aspects of the functioning of methods of correction of judicial errors in foreign countries in our criminal procedure legislation.

\section{Among them there are such as:}

- Specification of the persons who have the right to initiate a review of court decisions and the limits of their rights to review; 
- Determining the limits of consideration in higher courts depending on the content of submitted complaints (petitions, protests);

- Using the possibilities of information technologies to ensure the speed and efficiency of judicial proceedings in regulating the use of videoconferencing in the conduct of judicial proceedings (participation of a convict in prison; examination of evidence, examination of witnesses, etc.);

- Concretization of the grounds and subject of examination in higher courts, aimed at strengthening the responsibility of participants in criminal proceedings for the timely and qualitative use of the right to review court decisions;

- Provide for preliminary review by a court of cassation, as well as the possibility of involving specialists to obtain an opinion. For example, representatives of the academic community may be involved as specialists, which will allow, on the one hand, to obtain a constructive and professionally prepared opinion on legal issues and, on the other hand, to ensure the integration of education, science and practice;

- Exclusion of supervisory review proceedings and regulation of the reopening of proceedings in newly discovered circumstances as an independent way of reviewing court decisions in order to ensure the implementation of the principle of legal certainty and finality of court decisions;

- In case of introduction of procedural agreements into the criminal procedure legislation of the institute of procedural agreements, it is also necessary to provide for the peculiarities of revision of court decisions in the application of the said institute.

One of the most important features of the institution of judicial review is the existence of separate separate courts (separate from the courts of first instance). In our opinion, consideration of the issue of establishing courts of appeal should be conducted in a comprehensive manner. Together with the decision to establish independent courts of appeal in the system of courts, it is necessary to provide a place for consideration of criminal cases in cassation order. Reform of the judicial system with a view to establishing courts of appeal and cassation proceedings will help prevent possible influence of first instance judges on decisions of higher instance judges and will contribute to objective and impartial resolution of the case. When considering the establishment of separate courts of appeal and cassation, it would be possible to use the experience of both foreign countries (England, France, Austria, Albania, Belgium, Greece, Lithuania and others) and neighboring countries, among which is the experience of the judicial system of the Russian Federation, the Republic of Armenia and the Republic of Azerbaijan.

\section{REFERENCES}

1. Исаева К.А., Абдукаримова Н.Э., Воронцова И.Н. К вопросу об отдельных тенденциях и реформирования уголовно-процессуального законодательства в странах СНГ // Полицейская и следственная деятельность. - 2018. - № 2. - С. 9 - 15. - C.9. Ibid.
2. Апелляция, кассация, надзор: новеллы ГПК РФ, УПК РФ. Первый опыт критического осмысления / под ред.Н.А.Колоколова. - М.: Юрист, 2011; Головко Л.В. Новеллы УПК РФ (закон от 29 октября 2010 года): прогресс или институционный хаос? // Апелляция, кассация, надзор: новеллы ГПК РФ, УПК РФ. Первые результаты применения. В 2 ч. Ч.1. / под общ.ред.Н.А.Колоколова. - М.: Юрлитинформ, 2015. - С. 487-503; Колоколов Н.А. Апелляция: лиха беда начало! // Юридическая газета. - 2011. - № 10. - С.1213. и др.

3. This is also evidenced by Kolokolov's observation that the analysis of appeals (representations) filed with the courts shows that the participants of the process, first of all, lawyers and prosecutors, are not able to write them // См. об этом: Апелляция, кассация, надзор: применение УПК РФ: монография / под общ.ред. докт.юрид.наук Н.А.Колоколова. - М. Юрлитинформ, 2018. - 464 с. - С. 6.

4. Победкин A.B. ibid - C. 46-50.

5. Уголовный процесс: учебник / С.В.Зуев, К.И.Сутягин. - Челябинск: Издательский центр ЮУрГУ, 2016. -563 с. - С.19.

6. Указ. работа. - С.431

7. For information, in the criminal procedure legislation of the Kyrgyz Republic and the Republic of Kazakhstan these decisions are called "judicial acts", and in Ukraine "judicial decisions".

8. Уголовный процесс: учебник / С.В.Зуев, К.И.Сутягин. - Челябинск: Издательский центр ЮУрГУ, 2016. - 563 с. - С.439.

9. Уголовный процесс: учебник / С.В.Зуев, К.И.Сутягин. - Челябинск: Издательский центр ЮУрГУ, 2016. - 563 с. - С.439.

10. Романова А.А. Современное апелляционное производство в уголовном процессе России: диссертация ... кандидата юридических наук: 12.00.09 / Романова Анастасия Андреевна; [Место защиты: ФГКОУВО Нижегородская академия Министерства внутренних дел Российской Федерации], 2017. // http://www.dslib.net/kriminal-process/sovremennoeapelljacionnoe-proizvodstvo-v-ugolovnom-processerossii.html

11. The data obtained during the interviews with judges of the courts of the constituent entities of the Russian Federation indicate that judges simply cannot physically reconsider the volume of criminal cases that come to the appeal instance. Most of the judges interviewed agreed with the maintenance of a kind of "procedural filter" that would allow them to select those criminal cases in which a full-fledged appeal procedure should actually be conducted. // Романова Анастасия Андреевна. Современное апелляционное производство в уголовном процессе России: диссертация ... кандидата юридических наук: 12.00.09 / Романова Анастасия Андреевна; [Место защиты: ФГКОУВО Нижегородская академия Министерства внутренних дел Российской Федерации], 2017. http://www.dslib.net/kriminal-process/sovremennoeapelljacionnoe-proizvodstvo-v-ugolovnom-processerossii.html 
12. They are limited by both the available staff capacity and the budget ceiling for resources // Скляренко М.В. Система правоохранительных органов, адвокатуры и судов, гарантирующих деятельность механизма обжалования, проверки и пересмотра судебных решений в уголовном процессе // См. об этом: Апелляция, кассация, надзор: применение УПК РФ: монография / под общ.ред. докт.юрид.наук Н.А.Колоколова. - М.: Юрлитинформ, 2018. - 464 с. - С. 17.

13. Апелляция, кассация, надзор: применение УПК РФ: монография / под общ.ред. докт.юрид.наук Н.А.Колоколова. - М.: Юрлитинформ, 2018. - 464 с. - С. 17-18.

14. Уголовный процесс: учебник / С.В.Зуев, К.И.Сутягин. - Челябинск: Издательский центр ЮУрГУ, 2016. - 563 с. - С.469.

15. Свиридов М.К. Вопросы совершенствования кассационного производства в российском уголовном процессе // Вестник Томского государственного университета. Право. - 2017. - № 23.- С. 73. // https://cyberleninka.ru/article; Червоткин A.C. Апелляция и кассация: пособие для судей. - М.: Проспект, 2010. - 336 с. - С. 30-31.

16. Червоткин А.С. Апелляция и кассация: пособие для судей. - М.: Проспект, 2010. - 336 с. - С. 32.

17. Уголовный процесс: учебник / С.В.Зуев, К.И.Сутягин. - Челябинск: Издательский центр ЮУрГУ, 2016. - 563 с. - С.469.

18. Свиридов М.К. Вопросы совершенствования кассационного производства в российском уголовном процессе // Вестник Томского государственного университета. Право. - 2017. - № 23. - С. 73. // https://cyberleninka.ru/article.

19. ${ }^{1}$ Дикарев И.С. Надзорно-кассационная форма пересмотра судебных решений в уголовном процессе. -Волгоград: Изд-во ВолГУ, 2016. - 400 с. C. 30.

20. Свиридов М.К. Вопросы совершенствования кассационного производства в российском уголовном процессе // Вестник Томского государственного университета. Право. - 2017. - № 23. - С. 75. // https://cyberleninka.ru/article.

21. Апелляция, кассация, надзор: применение УПК РФ: монография / под общ.ред. докт.юрид.наук Н.А.Колоколова. - М.: Юрлитинформ, 2018. - 464 с. - C. 427.

22. If a court finds that a law or other regulatory legal act to be applicable infringes on the human and civil rights and freedoms enshrined in the Constitution of the Republic of Kazakhstan, it is obliged to suspend proceedings and apply to the Constitutional Council of the Republic of Kazakhstan with a view to declaring the act unconstitutional (article 10, paragraph 2, of the Code of Criminal Procedure)

23. Уголовный процесс: учебник / С.В.Зуев, К.И.Сутягин. - Челябинск: Издательский центр ЮУрГУ, 2016. - 563 с. - С.477.

24. Уголовный процесс: учебник / С.В.Зуев, К.И.Сутягин. - Челябинск: Издательский центр ЮУрГУ, 2016. - 563 с. - С.479.

25. Свиридов М.К. Вопросы совершенствования кассационного производства в российском уголовном процессе // Вестник Томского государственного университета. Право. - 2017. - № 23. - С. 79. // https://cyberleninka.ru/article.

26. Сухова О.А. Институт кассации в уголовном процессе России и Франции: генезис и сравнительноправовой анализ современного состояния в контексте соответствия международному стандарту. // Вестник
Удмуртского университета. - 2014. - Выпуск 2. - С. 190-191.

27. Сухова О.А. Институт кассации в уголовном процессе России и Франции: генезис и сравнительноправовой анализ современного состояния в контексте соответствия международному стандарту. // Вестник Удмуртского университета. - 2014. - Выпуск 2. - С. 197.; а также: Международный пакт о гражданских и политических правах. Принят резолюцией 2200 А $\underline{(\mathrm{XXI})}$ Генеральной Ассамблеи от 16 декабря 1966 года.

https://www.un.org/ru/documents/decl_conv/conventions /pactpol.shtml.

28. Ведищев Н.П. Возобновление производства по уголовному делу ввиду новых или вновь открывшихся обстоятельств в системе уголовного судопроизводства (российский опыт и международная практика): автореферат дисс. канд. юрид наук. - Саратов, 2012. // http://dissers.ru/avtoreferati-kandidatskihdissertatsii1/a1007.php

29. In the Russian Federation - Resumption of criminal proceedings in view of new or newly discovered circumstances, chapter 49 of the Code of Criminal Procedure; in Kazakhstan - Resumption of criminal proceedings in respect of newly discovered circumstances, chapter 53 of the Code of Criminal Procedure; in the Kyrgyz Republic - Resumption of proceedings in respect of newly discovered or exceptional circumstances, chapter 34 of the Code of Criminal Procedure; in Ukraine - Resumption of cases in respect of new or newly discovered circumstances, chapter 53 of the Code of Criminal Procedure.

30. Уголовный процесс: учебник / С.В.Зуев, К.И.Сутягин. - Челябинск: Издательский центр ЮУрГУ, 2016. - 563 с. - С.487.

31. Ведищев Н.П. Возобновление производства по уголовному делу ввиду новых или вновь открывшихся обстоятельств в системе уголовного судопроизводства (российский опыт и международная практика): автореферат дисс. канд. юрид наук. - Саратов, 2012. // http://dissers.ru/avtoreferati-kandidatskihdissertatsii1/a1007.php

32. Давыдов В.А. Возобновление уголовного судопроизводства ввиду новых или вновь открывшихся обстоятельств: автореферат дис.... докт. юрид. наук. - М., 2011. - С.1. // https://www.dissercat.com/content/ vozobnovlenieugolovnogo-sudoproizvodstva-vvidu-novykh-ili-vnovotkryvshikhsya-obstoyatelstv.

33. Ведищев Н.П. Возобновление производства по уголовному делу ввиду новых или вновь открывшихся обстоятельств в системе уголовного судопроизводства (российский опыт и международная практика): автореферат дисс. канд. юрид наук. - Саратов, 2012. // http://dissers.ru/avtoreferati-kandidatskihdissertatsii1/a1007.php

34. Уголовный процесс: учебник / С.В.Зуев, К.И.Сутягин. - Челябинск: Издательский центр ЮУрГУ, 2016. - 563 с. - С.487.

35. В порядке, установленном пунктом 2) части второй статьи 335 УПК Республики Казахстан. 
36. Давыдов В.А. Возобновление уголовного судопроизводства ввиду новых или вновь открывшихся обстоятельств: автореферат дис.... докт. юрид. наук. - М., 2011. - C.5. // https://www.dissercat.com/content/ vozobnovlenieugolovnogo-sudoproizvodstva-vvidu-novykh-ili-vnovotkryvshikhsya-obstoyatelstv.

37. Refusal is possible before the start of the trial and subsequently the person who refused the application does not have the right to re-apply to the court on the same grounds.

38. Жиноят ишлари бўйича суд амалиёти(Crimes of criminal court operation) // Журнал Правосудие. 2019. - № 7. - C. 19-21.

39. Crimes of criminal court operation Жиноят ишлари бўйича суд амалиёти (Crimes of criminal court operation) // Журнал Правосудие. - 2019. - № 7. - С. 21,27 